\title{
A laboratory study on groundwater quality and mass movement occurrence
}

\author{
Jen-Chen Fan · Che-Hsin Liu · Chih-Hsiang Yang • \\ Hsiao-Yu Huang
}

Received: 28 January 2008/Accepted: 9 June 2008/Published online: 8 July 2008

(C) Springer-Verlag 2008

\begin{abstract}
In this study, soil samples collected from the sides of two streams with high debris flow potential at Shenmu and Fengchiou village in Nantou County, Taiwan, were used for seepage tank tests in the laboratory. While the tests were being conducted, observations were made to investigate the relationships among displacement of the slope, quality of the seepage water and occurrence of mass movement. The results showed that according to the change rate, displacement could be divided into two stages, namely, the initial failure displacement stage and primary failure displacement stage. While the displacement of the slope was in primary failure displacement stages, the probability of slope failure became much higher. Before general slope failure, electrical conductivity (EC) and sulfate ion $\left(\mathrm{SO}_{4}{ }^{2-}\right)$ concentration of the seepage water increased significantly. The time when EC of the seepage water started to increase rapidly was much earlier than that when displacement of the slope started to increase significantly. Therefore, from the hazard mitigation view, there will be a longer time for response if EC of the seepage water was monitored.
\end{abstract}

Keywords Debris flow - Mass movement . Displacement · Electrical conductivity $\cdot$ Sulfate ion

J.-C. Fan $(\bowtie)$ · C.-H. Liu · C.-H. Yang

Graduate Institute of Bioenvironmental Systems Engineering,

National Taiwan University 1, Sec. 4, Roosevelt Rd.,

Taipei 10617, Taiwan, ROC

e-mail: jcfan@ntu.edu.tw

H.-Y. Huang

Soil and Water Conservation Bureau, 6, Guanghua Rd.,

Nantou 54044, Taiwan, ROC

e-mail: shiaoyue@mail.swcb.gov.tw

\section{Introduction}

Taiwan is a small island with high and steep mountains, short and rushing streams, and vulnerable geologic conditions. During typhoon and rainy seasons, mass movements such as landslides and debris flow occur quite often in slopeland area, and result in great loss of human lives, property and public facilities (Chang and Chien 2007). For instance, Toraji Typhoon on 30 July 2001 caused the greatest casualties and property loss in the past two decades and triggered a most disastrous and unforgettable debris flow (Fan et al. 2003). This kind of natural hazard occurs rather frequently in Taiwan.

Landslides occurring in a watershed upstream of the stream with high potential of debris flow may not only cause immediate hazard but also provide the materials for the debris flow. In traditional methods of slope stability analysis (including total stress and effective stress methods), such as Culmann's method, Taylor's method, circular failure surfaces method, ordinary method of slices, Bishop's simplified method of slices, Spencer's and Janbu's method of slices, the slope is considered to be under a condition of plane strain (Lambe and Whitman 1979; Das 1998) and progressive failure is not considered. In other words, it is assumed during the failure of the slope, the stresses distributed on the failure surface reach critical shear strength at the same time. To simplify the analysis, in different methods, different assumptions were made on the side forces of the slices, force equilibrium of the slices, friction of the slices and so forth to reduce the redundancies. As for calculating the safety factor, it is obtained from the value of the resisting force on the potential failure surface divided by that of the driving force. To reduce the redundancy, the safety factors of all slices are assumed to be equal, i.e., all the slices will either not fail or fail at the same time. 
In reality, the above-mentioned assumptions may not be correct. Usually, local failure occurs initially and then gradually with the development of the failure surface, general slope failure occurs. Until now, most of the data observed in the field are physical properties such as groundwater level, pressure, displacement and the data observed by inclinometer, extensometer and strain gage etc. Using these observation methods, it is difficult to predict the slope hazards timely and effectively. Until now, few studies have been related to chemistry methods. These studies are described as follows. Aoki (1998) conducted long-term groundwater monitoring at the Mushi landslip area in Niigata, Japan. He found that at a certain time before the landslip occurs, the deep groundwater level will rise and the concentration of hydrogen carbonate ions $\left(\mathrm{HCO}^{3-}\right)$, chloride ions $\left(\mathrm{Cl}^{-}\right)$and sodium ions $\left(\mathrm{Na}^{+}\right)$will change, resulting in an increase in electrical conductivity (EC). Ibe and Ebe (2000) collected water and soil samples at different sections and depths from Cross River in Nigeria after debris flow occurred. Then they conducted a series of environmental chemistry experiments, and found out that the concentrations of magnesium ions $\left(\mathrm{Mg}^{2+}\right)$ and sulfate ions $\left(\mathrm{SO}_{4}{ }^{2-}\right)$ increased downstream. Results of soil analysis also showed the presence of potassium ion $\left(\mathrm{K}^{+}\right)$, magnesium ion $\left(\mathrm{Mg}^{2+}\right)$, calcium ion $\left(\mathrm{Ca}^{2+}\right)$, and chloride ion $\left(\mathrm{Cl}^{-}\right)$.

Based on the studies noted above, it was hypothesized that soil deformation triggered by rainfall and/or a rise of groundwater caused the change in groundwater quality downstream from slope failures. Therefore, in this study, a series of laboratory experiments were conducted to investigate relationships among ion concentration, electrical conductivity of seepage water and mass movement occurrence. There are quite a few efforts needed to be made to achieve the final goal that monitoring of groundwater quality can be used for predicting the occurrence of mass movement, yet it is expected that the findings in this study are a small step toward this goal.

\section{Research method}

Electrical conductivity (EC) of seepage water is a combined index of seepage water quality. Therefore, in this study, a series of indoor seepage tank tests were conducted to simulate slope failures because of rises in the groundwater level. During the tests, slope displacements, EC and ion concentrations of seepage water were monitored.

Soil test for samples

Soil samples for the indoor seepage tank tests of this study were collected from the sides of two streams with high debris flow potential at Shenmu village and Fengchiou village in Sinyi Township, Nantou County, Taiwan, where debris flows occur frequently. Among 199 debris flow potential streams in Nantou County, the streams of Shenmu village and Fengchiou village were numbered "Nantou 037" and "Nantou 029", respectively, by the Soil and Water Conservation Bureau in Taiwan, as shown in Fig. 1. The basic physical properties of the soil samples were determined using ASTM standards (Table 1; Fig. 2). The tests of specific gravity, liquid limit and plastic limit were performed twice, whereas the sieve and hydrometer analyses for determining particle size distributions were performed only once.

\section{Description of the tank for tests}

The dimension of the seepage tank used in this study was $100 \times 30 \times 30 \mathrm{~cm}$ as shown in Fig. 3. There were three observation holes inside the tank, and one outside.

Using the holes, the variation of EC of water in and out of the tank was monitored. EC meter No. 1 was placed at the water source to record the variation of EC near the water inlet and excess water outlet. Excess water outlet was used to maintain the water level. EC meter No. 2 was placed inside the soil sample and about $30 \mathrm{~cm}$ from the filter and inlet. It was used to record the variation of EC upstream of the soil slope. A 1 in. hole was made $15 \mathrm{~cm}$ from the opening of the seepage tank and EC meter No. 3 was put there to record the variation of EC downstream of the soil slope. EC meter No. 4 was placed at the tank outlet to record the EC of seepage water coming out of the sample. A data logger was used to record data from different EC meters. Apart from these, to observe the soil sample failure, horizontal and vertical displacement meters were placed at the soil slope to monitor soil displacement. Further, a 1 in. hole was made near the opening of the tank

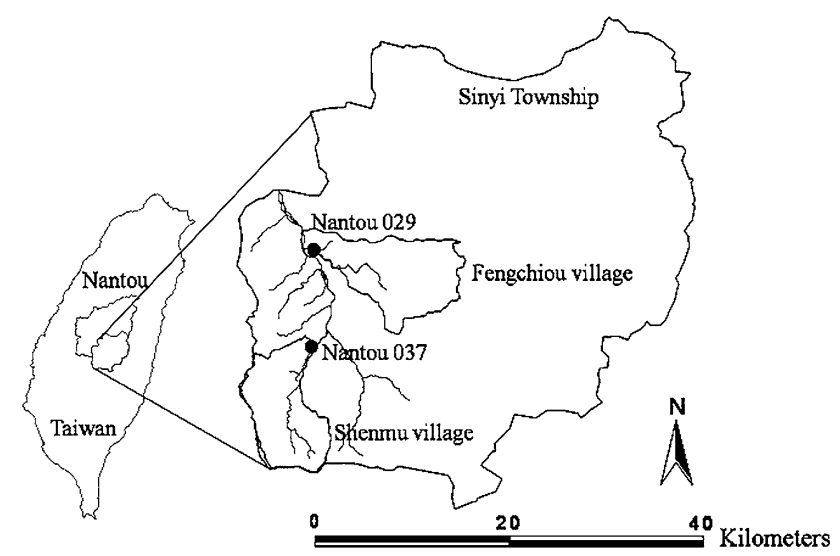

Fig. 1 The location of the test sample collection sites (Sinyi Township of Nantou County in Taiwan) 
on the other side of EC meter No. 3 and a valve was installed to collect water samples for testing.

Sample preparation

To make the physical properties of the test samples similar to their in-situ counterparts, the scalp-and-replace method (Houston and Walsh 1993; Lin 1986; Chen et al. 1995) was used to modify the particle size distribution curves of the soil samples. The plus 1.5 in. $(38.1 \mathrm{~mm})$ material was removed before compaction and replaced with an equal weight of No. 4 to 1.5 in. $(38.1 \mathrm{~mm})$ material. Sometimes,

Table 1 Basic physical properties of soil samples from Shenmu village and Fengchiou village

\begin{tabular}{lll}
\hline Parameters & \multicolumn{2}{l}{ Sample location } \\
\cline { 2 - 3 } & Shenmu village & Fengchiou village \\
\hline Specific gravity $\left(G_{\mathrm{s}}\right)^{\mathrm{a}}$ & 2.71 & 2.65 \\
Void ratio $(e)^{\mathrm{b}}$ & 0.59 & 0.54 \\
$D_{10}(\mathrm{~mm})$ & 0.06 & 0.07 \\
$D_{30}(\mathrm{~mm})$ & 4.76 & 4.24 \\
$D_{60}(\mathrm{~mm})$ & 34.90 & 20.70 \\
$C_{\mathrm{u}}$ & 581.67 & 295.71 \\
$C_{\mathrm{z}}$ & 10.82 & 12.41 \\
Liquid limit (LL, \%) & 37 & 28 \\
Plastic limit (PL, \%) & 29 & 22 \\
Plastic index (PI, \%) & 8 & 6 \\
USCS classification & $\mathrm{GM}$ & $\mathrm{GM}-\mathrm{GC}$ \\
\hline
\end{tabular}

${ }^{\text {a }}$ The specific gravity is defined as $G_{\mathrm{s}}=\rho_{\mathrm{s}} / \rho_{\mathrm{w}}=\gamma_{\mathrm{s}} / \gamma_{\mathrm{w}}$, therefore, it is dimensionless

b The void ratio is the field value this method is referred to as the procedure for replacement of oversized aggregate. In Taiwan, this method has been named the "equal weight replacement" method, and the "modified weight replacement" method because of different translations from Chinese to English.

According to ASTM (2003, D2850; 2004a, D3080; 2004b, D4767), the largest particle size should be smaller than one-sixth the specimen diameter or thickness. Therefore, $1.5 \mathrm{in}$., which is smaller than one-sixth the smallest dimension (namely $30 \mathrm{~cm}$, approximately $12 \mathrm{in}$.) of the tank, was selected as the maximum particle size. The maximum particle sizes of the soil samples collected from Shenmu and Fengchiou, in Nantou, were much greater than 1.5 in. (as can be seen in Fig. 2); therefore, the scalp and replace method (or the equal weight replacement method) was used to adjust the curves as shown in Fig. 4.

The average dry unit weights and moisture contents of Shenmu village and Fengchiou village in-situ were determined to be $16.63 \mathrm{kN} / \mathrm{m}^{3}$ and $15.6 \%$, and $16.71 \mathrm{kN} / \mathrm{m}^{3}$ and $12.1 \%$, respectively. The method used in this study to determine the field density is similar to that of Bertram (1973). However, the diameters of the holes were $1 \mathrm{~m}$ instead of $6 \mathrm{ft}$. For each test in the laboratory, the weight of dry soil and water were calculated according to the dry unit weight and moisture content in-situ, the modified particle size distribution curve and the sample volume in the seepage tank. The dry soil and water for each corresponding layer and batch were then weighed, well mixed, covered and kept undisturbed for at least $24 \mathrm{~h}$ to allow the soil to have evenly distributed moisture content. The moisture contents of the soil samples were controlled as close as that in the field, i.e. only $1 \%$ of error was allowed. Compared with the most common individual moisture specification in
Fig. 2 Particle-size distribution curves for test samples collected from Shenmu village and Fengchiou village

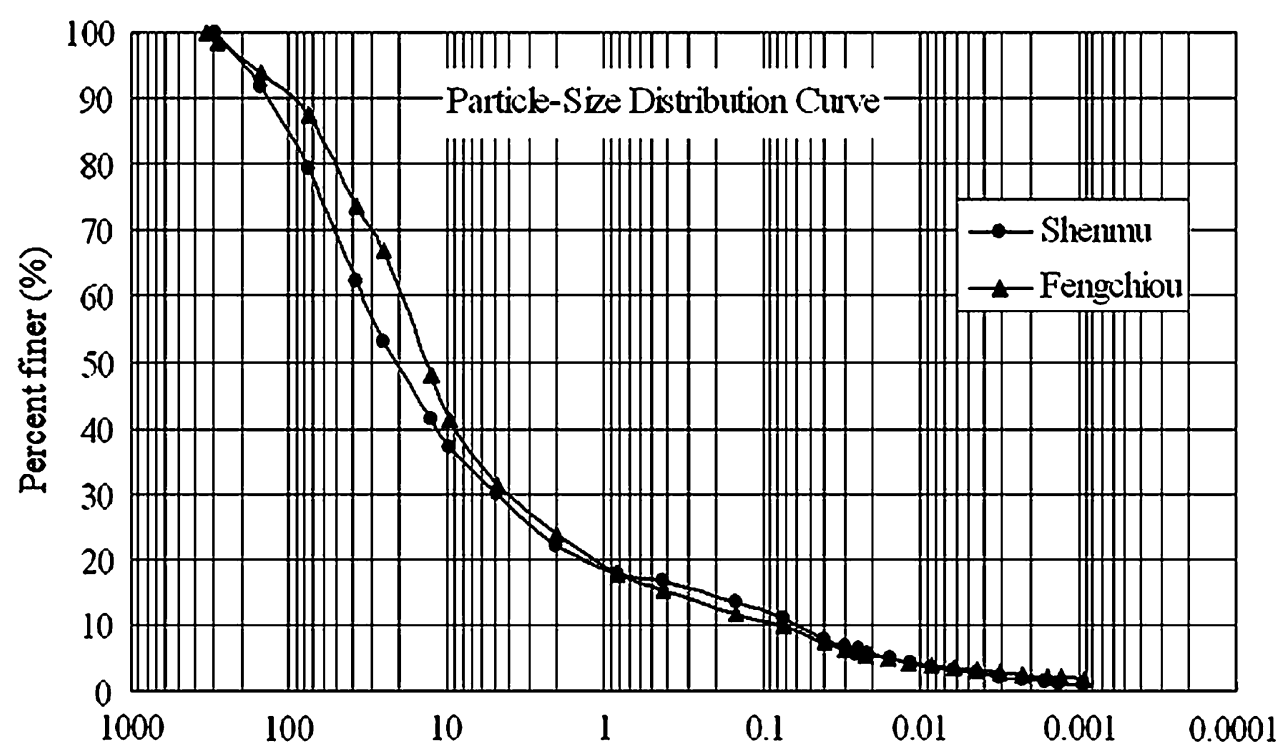


Fig. 3 Diagram of seepage tank

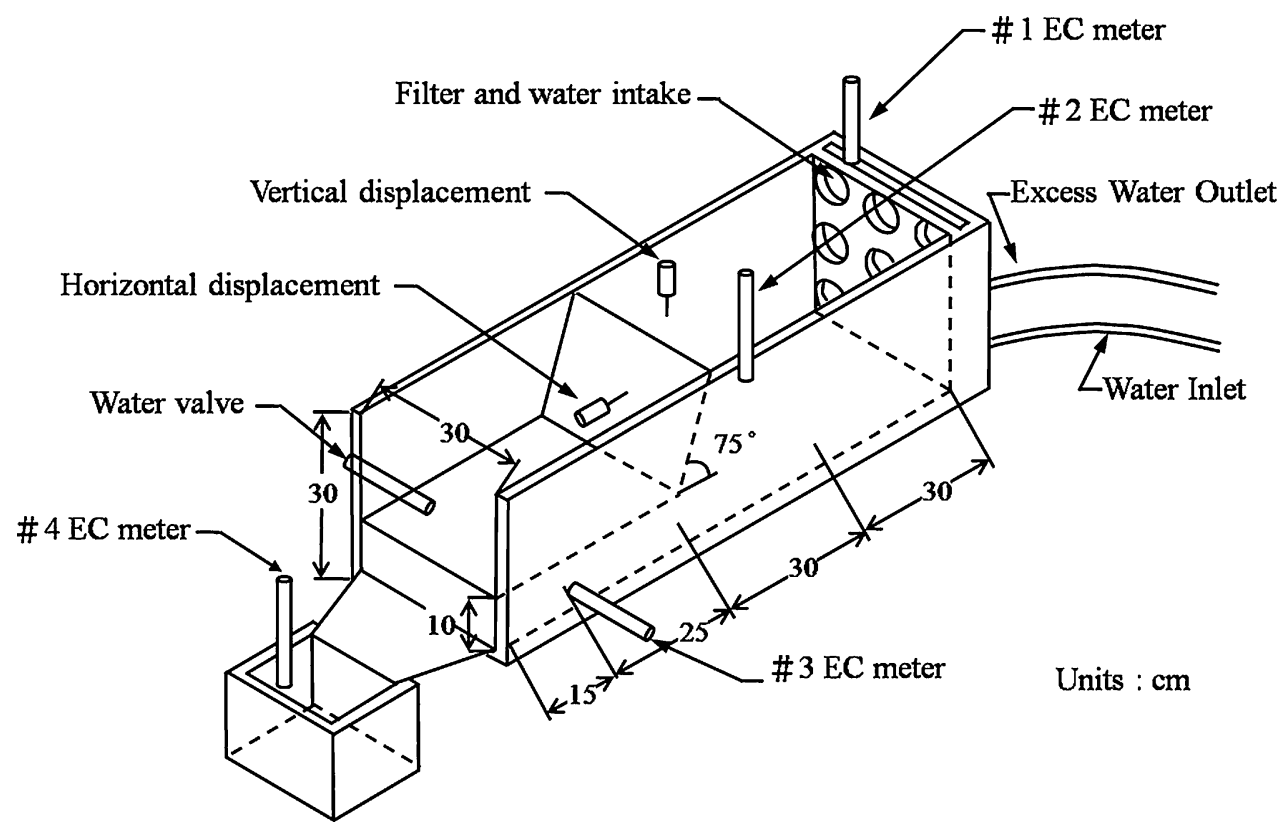

Fig. 4 The modified particle distribution curves by using the scalp-and-replace method for the soil samples from Shenmu village and Fengchiou village
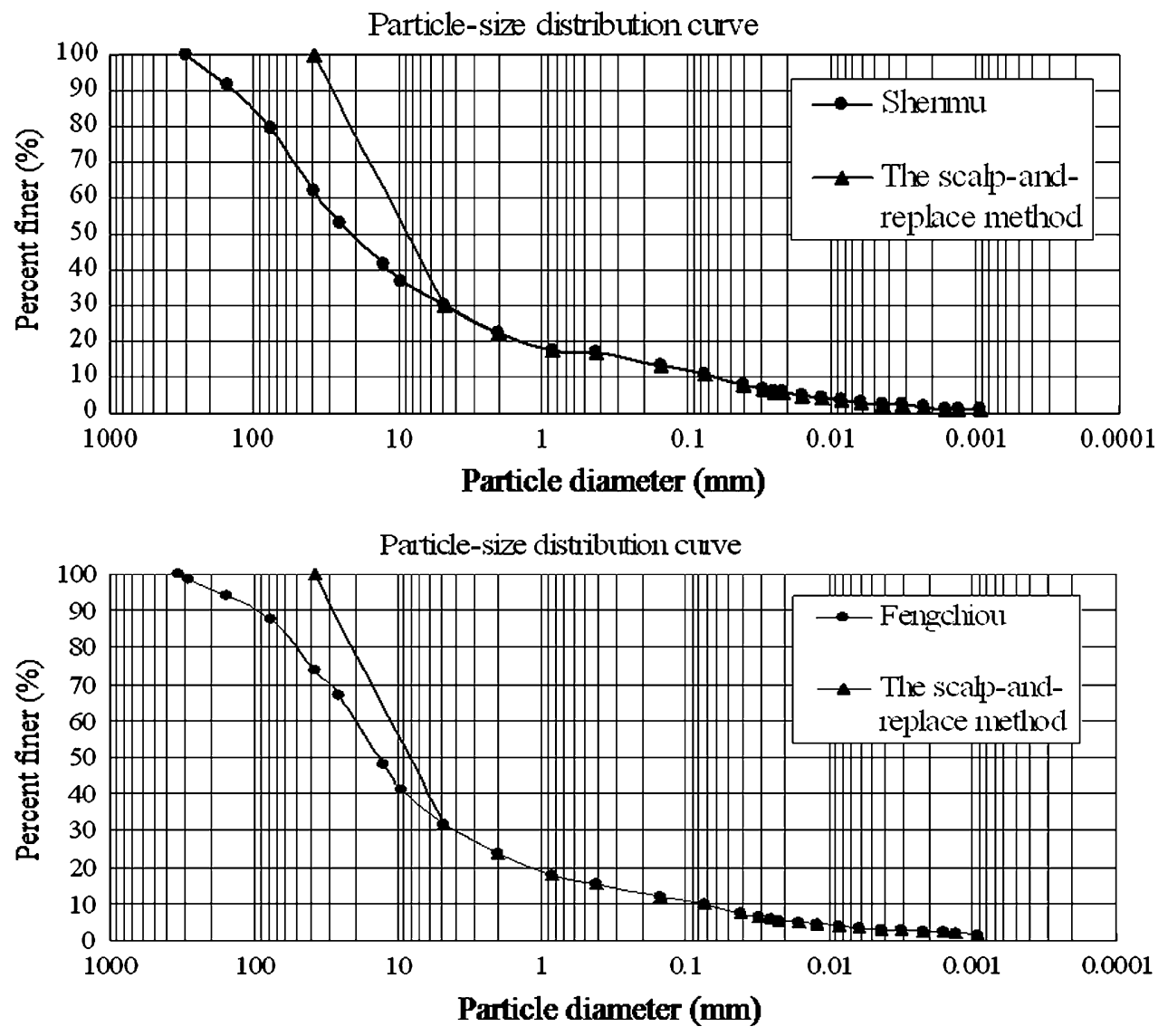

the United States, which was OMC $\pm 2 \%$ (Parsons et al. 2001); the controlled range of moisture content seems reasonable. When everything was ready, the sample was put into the tank in five layers and compacted for each layer. After the first two layers (with a total height of $10 \mathrm{~cm}$ ) were prepared, a metal slab $40 \mathrm{~cm}$ from the opening of the tank was installed to make a $75^{\circ}$ slope. Then, the rest of the three layers (with a total height of $20 \mathrm{~cm}$ ) were put in and compacted to ensure that the dry unit weight and the moisture content were close to those in the field. 


\section{Results and discussion}

Slope failure in the seepage tank was triggered by a groundwater rise. The slope angle was $75^{\circ}$. Displacements of the slope and variation of EC were monitored and recorded. Aside from these, water samples were collected from the valves for water quality analysis.

\section{Variation of seepage water level}

While the seepage tank experiments were being conducted, the water levels at the source as well as at different observation holes (the height from the bottom of the tank to the water level) were measured and recorded. The results were analyzed as follows.

The water head measurements consisted of two parts, namely, the water head at the source and that observed in the holes. Initially, a water head of $10 \mathrm{~cm}$ was maintained at the source and in the observation holes. Then, the water head at the source was increased by $0.5 \mathrm{~cm}$ every $10 \mathrm{~min}$. The head increase controlled at this rate was mainly to ensure that it was slow enough to allow the experiments to be successfully conducted and observed. The water heads at the source and in the observation holes were recorded every $10 \mathrm{~min}$. From the test results, it was found that the average water heads at the source and in the observation hole for No.3 EC sensor, and the average total failure time were $21.78 \mathrm{~cm}, 21.70 \mathrm{~cm}$ and $235.5 \mathrm{~min}$, respectively, for Shengmu village ( 2 sets of data in total); and $21.42 \mathrm{~cm}$, $21.23 \mathrm{~cm}$ and $228.3 \mathrm{~min}$, respectively, for Fengchiou village (three sets of data in total).

\section{Displacement analysis}

To investigate the soil mass displacement situation while the seepage water rose and the soil mass failed, vertical and horizontal displacement meters were installed at the outlet to record the data. From five sets data of the test results, it could be observed (see Figs. 5 6), from the start of slope displacement till general slope failure, displacement versus time curve could be divided into two parts, namely, initial failure displacement zone and primary failure displacement zone. In this curve, it could be seen that in the beginning, displacement increased slowly with time, however, after a certain time, displacement increased rapidly and resulted in general slope failure. Therefore, the displacement versus time curve was divided into two stages for further discussion as follows. (Note: In the following, horizontal displacement was used for discussion.)

1. Initial failure displacement stage: it was defined as the time from when slope displacement starts to occur till the time when displacement increased significantly.
The stage represents a sign that the slope might fall into an unstable situation after a certain time.

2. Primary failure displacement stage: in this stage, displacement increased significantly, subsequently resulting in general slope failure. Therefore, this stage was the most important part during mass movement monitoring.

In this study, the start time of the initial failure displacement stage was defined as the starting time of slope displacement $\left(t_{\mathrm{di}}\right)$; the time when general slope failure occurred was defined as the general slope failure time $\left(t_{\mathrm{df}}\right)$, while the time separating the two stages $\left(t_{\mathrm{pi}}\right)$ was defined as either the end of initial failure displacement or the start of primary failure displacement. As shown in Fig. 5, the results of the third set of tests of Fengchiou were used for description. In this figure, $t_{\mathrm{pi}}$ was the corresponding time where the slope steepness changed significantly (i.e. the maximum curvature). In this study, the difference between $t_{\mathrm{df}}$ and $t_{\mathrm{pi}}$ was defined as $\Delta t_{\mathrm{d}}$ (i.e., $\Delta t_{\mathrm{d}}=t_{\mathrm{df}}-t_{\mathrm{pi}}$ ). In other words, from the displacement observation view, $\Delta t_{\mathrm{d}}$ was the time needed for primary failure.

From the five sets of test data of Shenmu and Fengchiou (see Fig. 6; Table 2), it could be found that the average values of $t_{\mathrm{di}}, t_{\mathrm{pi}}$ and $t_{\mathrm{df}}$ for the two sets of test of Shenmu were 157.0, 207.0 and $235.5 \mathrm{~min}$, respectively; those for the three sets of test of Fengchiou 142.7, 214.3 and $228.3 \mathrm{~min}$, respectively. As for the average time needed for primary failure $\left(\Delta t_{\mathrm{d}}\right)$, for two sets of the tests of Shenmu and three sets of the tests of Fengchiou, they were 28.5 and $14.0 \mathrm{~min}$, respectively.

\section{Electrical conductivity (EC) analysis}

Electrical conductivity was monitored from the start of the test till the end of general slope failure. It could be seen in Fig. 6, for the five sets of tests, the initial values were slightly different and at the beginning the EC values

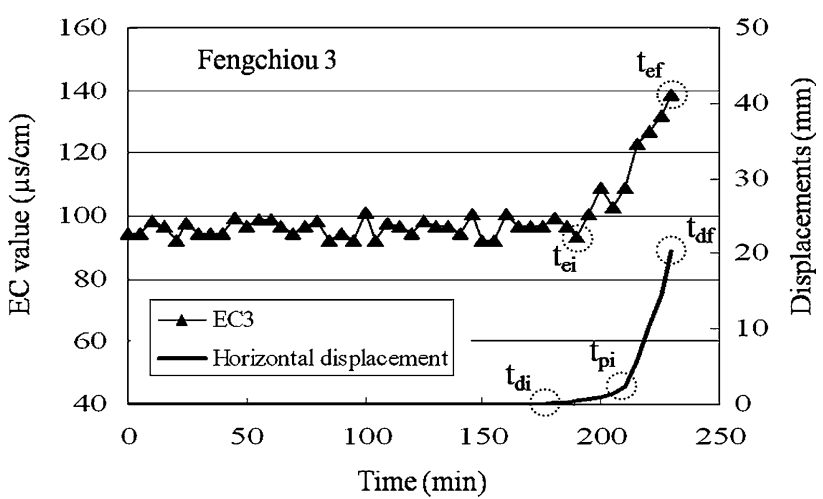

Fig. 5 Points of times defined for displacement-time curve and ECtime curve 
Fig. 6 Displacement and EC versus time curves of the five sets of tests of Shenmu and Fengchiou
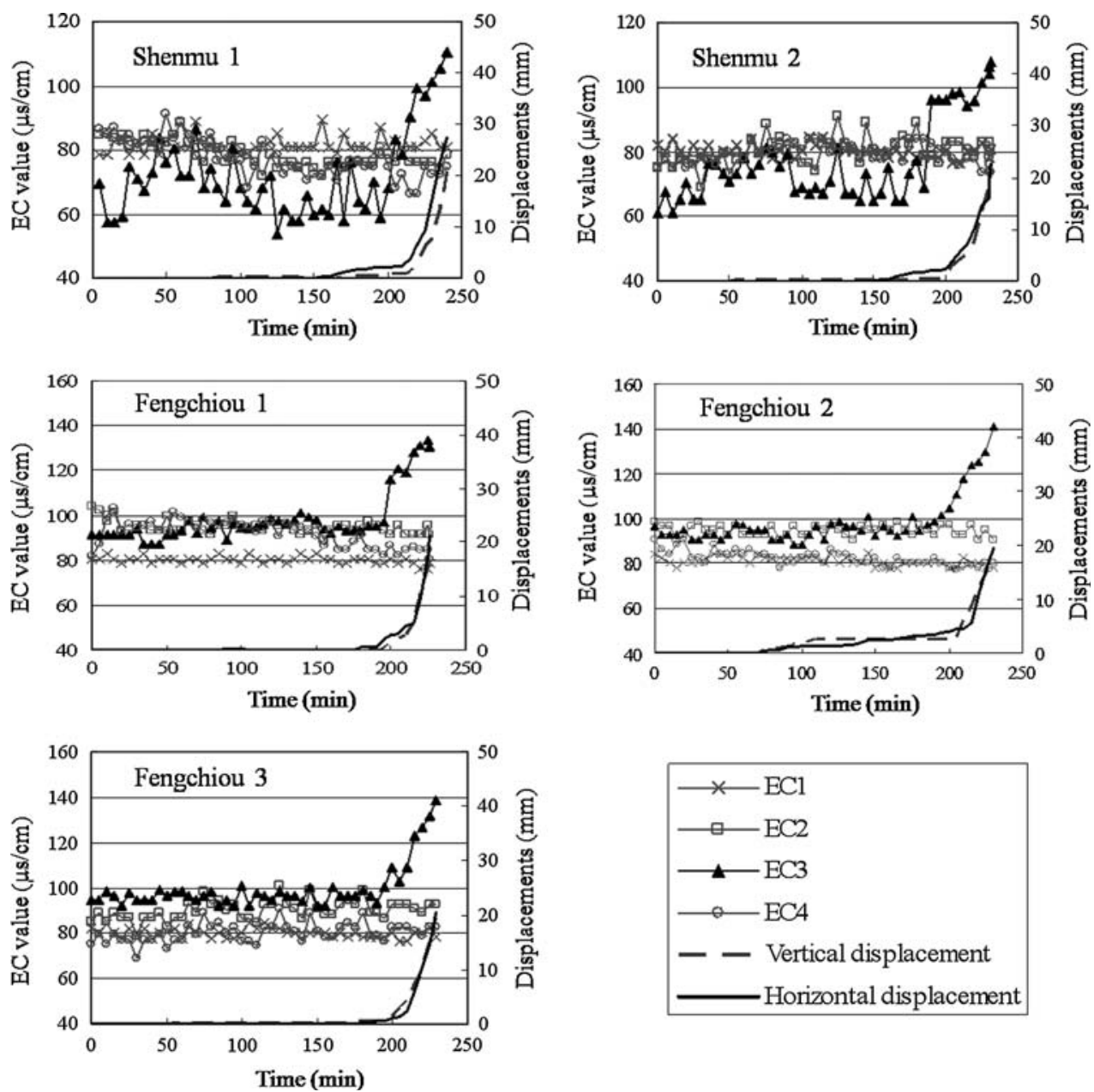

Table 2 Results of time and EC value of NO.3 EC meter for the five tests of Shenmu and Fengchiou

Test results

\begin{tabular}{lcccc} 
Location & & & & \\
\hline Shenmu 1 & Shenmu 2 & Fengchiou 1 & Fengchiou 2 & Fengchiou 3 \\
\hline 155 & 159 & 181 & 72 & 175 \\
240 & 231 & 226 & 230 & 229 \\
& & & & \\
196 & 184 & 184 & 181 & 191 \\
212 & 202 & 217 & 216 & 210 \\
240 & 231 & 226 & 230 & 229 \\
28 & 29 & 9 & 14 & 19 \\
44 & 47 & 42 & 49 & 38 \\
65 & 71 & 97 & 95 & 97 \\
105 & 109 & 131 & 141 & 139 \\
40 & 38 & 34 & 46 & 38 \\
62 & 54 & 35 & 48 & 39 \\
\hline
\end{tabular}

fluctuated and after a certain time they became more smooth. The EC values of No. 1 and No. 2 EC meters upstream of the potential failure surface did not change significantly. However, the EC values of No. 3 EC meter downstream of the potential failure surface increased significantly from $t_{\mathrm{pi}}$ to the end of general slope failure. 
In this study, the time when EC value started to increase significantly (the maximum curvature) was defined as the EC starting time of slope failure $\left(t_{\mathrm{ei}}\right)$. The EC value corresponding to $t_{\mathrm{ei}}$ was the $\mathrm{EC}$ starting value of slope failure $\left(\mathrm{EC}_{\mathrm{i}}\right)$. The ending time of EC monitoring $\left(t_{\mathrm{ef}}\right)$ was equal to general slope failure time $\left(t_{\mathrm{df}}\right)$, i.e., $t_{\mathrm{ef}}=t_{\mathrm{df}}$. The EC value corresponding to $t_{\mathrm{ef}}$ was $\mathrm{EC}_{\mathrm{f}}$ as shown in Fig. 5. In this study, the time difference between $t_{\mathrm{ei}}$ and $t_{\mathrm{ef}}$ was defined as $\Delta t_{\mathrm{e}}$. In other words, from the EC observation view, $\Delta t_{\mathrm{e}}$ was the time needed for slope failure. In the time period of $\Delta t_{\mathrm{e}}$, the increment of $\mathrm{EC}$ value was $\triangle \mathrm{EC}$, and $\Delta \mathrm{EC}=\mathrm{EC}_{\mathrm{f}}-$ $\mathrm{EC}_{\mathrm{i}}$.

As shown in Fig. 6 and Table 2, for two sets of the tests of Shenmu, the average values of $\Delta t_{\mathrm{e}}, \Delta \mathrm{EC}$ and the increase rate of EC during the time period of $\Delta t_{\mathrm{e}}(\% \Delta \mathrm{EC})$ were $45.5 \mathrm{~min}, 39.0 \mu \mathrm{s} / \mathrm{cm}$ and $58.0 \%$, respectively; for the three sets of the tests of Fengchiou, they were $43.0 \mathrm{~min}$, $39.3 \mu \mathrm{s} / \mathrm{cm}$ and $40.7 \%$, respectively.

\section{Water quality analysis}

The seepage water in the soil mass was collected every $30 \mathrm{~min}$ during each test for analysis to examine the variation in groundwater quality during slope failure. Water was collected from two different spots, namely, upstream (No. 2 EC meter) and downstream (No. 3 EC meter) of the potential slope failure zone. Eight kinds of chemical tests were performed to determine the concentrations of ions which were likely to change because of soil and rock deformation, according to the studies by Aoki (1998), and Ibe and Ebe (2000). The test items included: hydrogen carbonate $\left(\mathrm{HCO}_{3}{ }^{-}\right)$, chloride $\left(\mathrm{Cl}^{-}\right)$, sulfate $\left(\mathrm{SO}_{4}{ }^{2-}\right)$, nitrate $\left(\mathrm{NO}_{3}{ }^{-}\right)$, and tests for metal ions $\left(\mathrm{Ca}^{2+}, \mathrm{Mg}^{2+}, \mathrm{Na}^{+}, \mathrm{K}^{+}\right)$. From the test results, it could be found:

1. For all five sets of samples, either upstream or downstream of the soil mass, the concentration of chloride $\left(\mathrm{Cl}^{-}\right)$and nitrate $\left(\mathrm{NO}_{3}{ }^{-}\right)$showed no significant change throughout the tests. The concentrations of metal ions $\left(\mathrm{Ca}^{2+}, \mathrm{Mg}^{2+}, \mathrm{Na}^{+}, \mathrm{K}^{+}\right)$in the water were less than $10 \mathrm{mg} / \mathrm{l}$ with a variation no greater than $3 \mathrm{mg} / \mathrm{l}$. In addition, metal ion concentrations showed no significant changes before or after the slope failed.

2. For the three sets of samples from Fengchiou village, the hydrogen carbonate $\left(\mathrm{HCO}_{3}{ }^{-}\right)$ion concentrations upstream and downstream of the soil mass ranged from 15 to $30 \mathrm{mg} / \mathrm{l}$, while the concentration of the two sets of samples from Shenmu village varied from 5 to $15 \mathrm{mg} / \mathrm{l}$. Based on this observation, hydrogen carbonate $\left(\mathrm{HCO}_{3}{ }^{-}\right)$ion concentrations showed no significant changes before or after slope failure.

3. Sulfate ion $\left(\mathrm{SO}_{4}{ }^{2-}\right)$ concentrations upstream of the slope failure zone remained roughly unchanged during the tests. However before a soil mass failure, the downstream ion concentrations of the two sets of samples from Shenmu village rose from 11.7 to $21.7 \mathrm{mg} / \mathrm{l}$ and 12.2 to $22.4 \mathrm{mg} / \mathrm{l}$, respectively. The downstream ion concentrations of the three sets of samples from Fengchiou village rose from 15.0 to $25.1 \mathrm{mg} / \mathrm{l}, 14.5$ to $23.6 \mathrm{mg} / \mathrm{l}$ and 15.0 to $25.5 \mathrm{mg} / \mathrm{l}$, respectively (see Table 3 ).

After analyzing the ion concentrations of the five tests, it might be concluded as follows.

(1) Before slope failure caused by a rise in groundwater level, downstream sulfate ion $\left(\mathrm{SO}_{4}{ }^{2-}\right)$ concentrations tended to increase significantly, whereas upstream sulfate ion concentrations generally remained unchanged. (2) Concentrations of other ions including hydrogen carbonate $\left(\mathrm{HCO}_{3}{ }^{-}\right)$, chloride $\left(\mathrm{Cl}^{-}\right)$, nitrate $\left(\mathrm{NO}_{3}{ }^{-}\right)$and metal ion $\left(\mathrm{Ca}^{2+}, \mathrm{Mg}^{2+}, \mathrm{Na}^{+}, \mathrm{K}^{+}\right)$showed no significant changes either upstream or downstream.

Similar to electrical conductivity analysis as previously mentioned, the concentration of sulfate ion $\left(\mathrm{SO}_{4}{ }^{2-}\right)$ and displacement versus time curves were analyzed and plotted as shown in Figs. 7 and 8. In this study, the time when sulfate ion $\left(\mathrm{SO}_{4}{ }^{2-}\right)$ concentration started to increase significantly (the maximum curvature) was defined as the

Table 3 Analysis of the change in sulfate ion concentration upstream and downstream of the slope failure zone

\begin{tabular}{|c|c|c|c|c|c|c|c|c|c|c|}
\hline \multirow[t]{2}{*}{ Time (min) } & \multicolumn{5}{|c|}{ Upstream $\mathrm{SO}_{4}{ }^{2-}$ concentration $(\mathrm{mg} / \mathrm{l})$} & \multicolumn{5}{|c|}{ Downstream $\mathrm{SO}_{4}{ }^{2-}$ concentration $(\mathrm{mg} / \mathrm{l})$} \\
\hline & SM1 & SM2 & $\mathrm{FC} 1$ & $\mathrm{FC} 2$ & FC3 & SM1 & SM2 & $\mathrm{FC} 1$ & $\mathrm{FC} 2$ & FC3 \\
\hline 30 & 9.0 & 9.4 & 11.7 & 12.3 & 11.5 & 8.8 & 8.8 & 13.6 & 8.3 & 12.6 \\
\hline 60 & 9.4 & 9.7 & 10.8 & 11.1 & 11.0 & 9.2 & 10.6 & 13.8 & 11.7 & 13.8 \\
\hline 90 & 9.4 & 9.6 & 10.2 & 13.2 & 11.2 & 9.0 & 9.7 & 13.6 & 12.3 & 13.6 \\
\hline 120 & 9.3 & 9.2 & 10.8 & 11.8 & 10.8 & 9.4 & 10.3 & 14.0 & 12.8 & 13.7 \\
\hline 150 & 9.4 & 9.9 & 11.0 & 12.0 & 11.0 & 9.6 & 11.2 & 13.8 & 13.0 & 13.8 \\
\hline 180 & 8.8 & 9.7 & 10.6 & 10.8 & 11.4 & 11.4 & 11.5 & 13.6 & 12.6 & 13.6 \\
\hline 210 & 8.3 & 9.7 & 9.9 & 10.9 & 11.3 & 11.7 & 12.2 & 15.0 & 14.5 & 15.0 \\
\hline 240 & 8.7 & 9.7 & 10.4 & 11.2 & 11.3 & 21.7 & 22.4 & 25.1 & 23.6 & 25.5 \\
\hline
\end{tabular}


sulfate ion starting time of slope failure $\left(t_{\mathrm{si}}\right)$. The sulfate ion $\left(\mathrm{SO}_{4}{ }^{2-}\right)$ concentration corresponding to $t_{\mathrm{si}}$ was the sulfate ion starting value of slope failure $\left(S_{\mathrm{i}}\right)$; whereas the ending time of sulfate ion monitoring $\left(t_{\mathrm{sf}}\right)$ was equal to the general slope failure time $\left(t_{\mathrm{df}}\right)$, i.e., $t_{\mathrm{sf}}=t_{\mathrm{df}}$. The sulfate ion $\left(\mathrm{SO}_{4}{ }^{2-}\right)$ concentration value corresponding $t_{\mathrm{df}}$ was $S_{\mathrm{f}}$ as shown in Fig. 7. In this study, the time difference between $t_{\mathrm{si}}$ and $t_{\mathrm{sf}}$ was defined as $\Delta t_{\mathrm{s}}$. In other words, from the sulfate ion concentration observation view, $\Delta t_{\mathrm{s}}$ was the

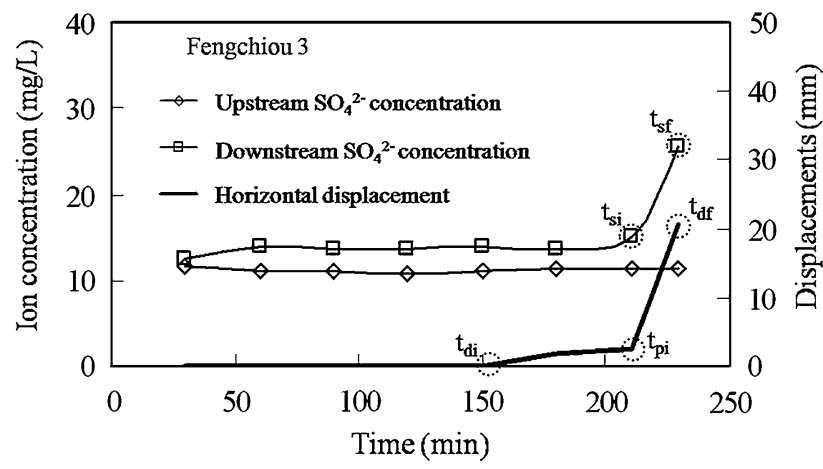

Fig. 7 Points of times defined for displacement-time curve and sulfate ion time curve time needed for slope failure. In the time period of $\Delta t_{\mathrm{s}}$, the increment of $\mathrm{SO}_{4}{ }^{2-}$ concentration was $\Delta S$, and $\Delta S=S_{\mathrm{f}}-S_{\mathrm{i}}$.

As shown in Fig. 8 and Table 4, for the two tests of Shenmu, the average values of $\Delta t_{\mathrm{s}}$, and $\Delta S$ and the increase rate of $\mathrm{SO}_{4}{ }^{2-}$ during the time period of $\Delta t_{\mathrm{s}}(\% \Delta S)$ were $25.5 \mathrm{~min}, 10.1 \mathrm{mg} / \mathrm{l}$ and $84.5 \%$, respectively; for the two tests of Fengchiou, they were $18.3 \mathrm{~min}, 9.9 \mathrm{mg} / \mathrm{l}$ and $66.7 \%$, respectively.

\section{General discussion}

From five sets of results of the seepage tank tests in the laboratory shown in Table 5, general discussion is as follows.

From the slope displacement observation view, from the start of slope displacement till general slope failure, displacement versus time curve could be separated into two parts, namely, the initial failure displacement stage and the primary failure displacement stage. That is to say, when the slope displacement fell into the primary failure displacement stage, the occurrence probability of mass movement notably increases.
Fig. 8 Displacement and sulfate ion versus time curves of the five tests of Shenmu and Fengchiou
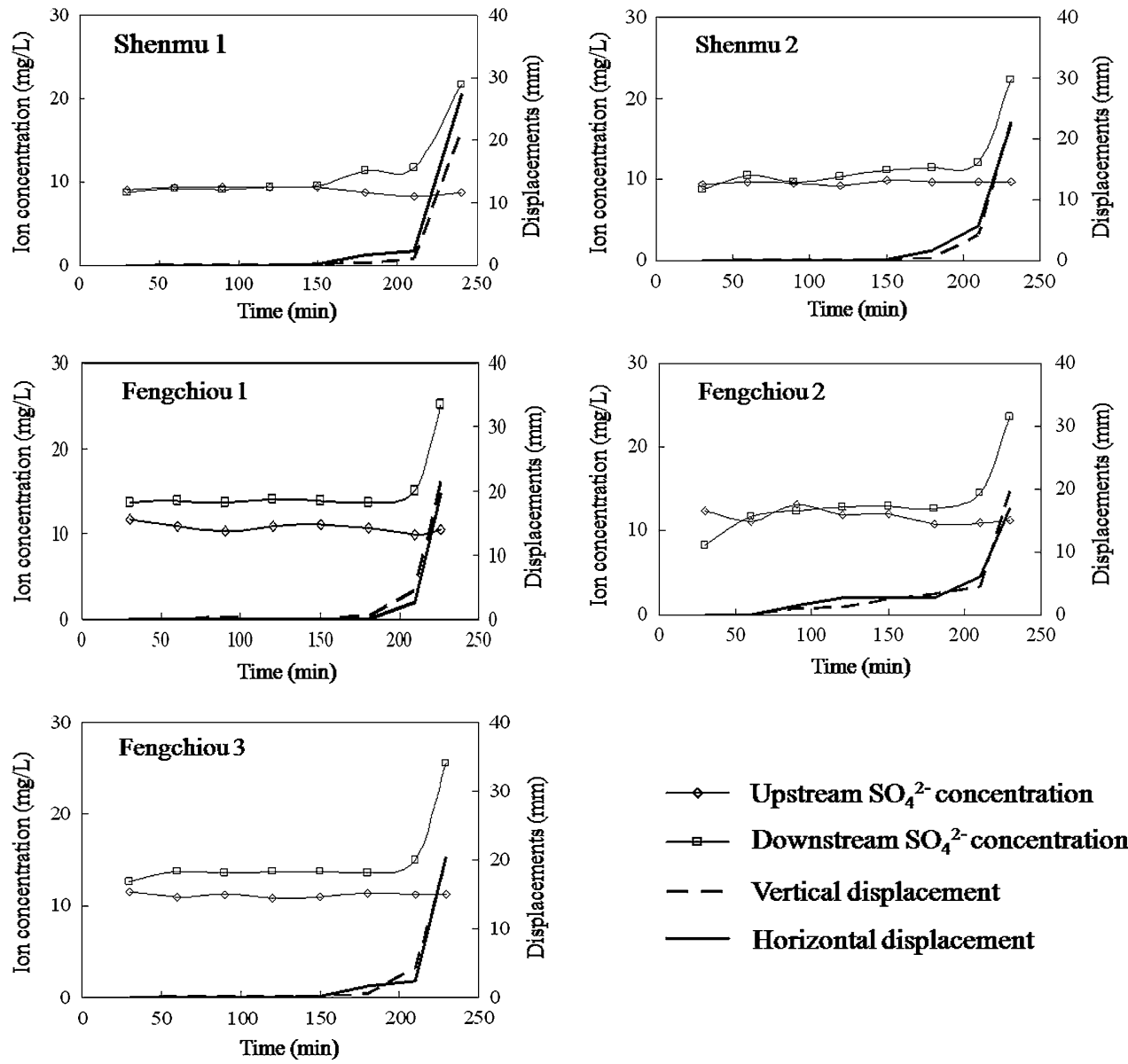
Table 4 Results of time and sulfate ion concentration value downstream for the five tests of Shenmu and Fengchiou

\begin{tabular}{|c|c|c|c|c|c|}
\hline \multirow[t]{2}{*}{ Test results } & \multicolumn{5}{|l|}{ Location } \\
\hline & Shenmu 1 & Shenmu 2 & Fengchiou 1 & Fengchiou 2 & Fengchiou 3 \\
\hline$t_{\mathrm{si}}\left(\right.$ the sulfate ion $\left(\mathrm{SO}_{4}{ }^{2-}\right)$ starting time of slope failure; $\left.\min \right)$ & 210 & 210 & 210 & 210 & 210 \\
\hline$t_{\mathrm{sf}}$ (the ending time of sulfate ion $\left(\mathrm{SO}_{4}{ }^{2-}\right)$ monitoring; $\left.t_{\mathrm{sf}}=t_{\mathrm{df}}, \min \right)$ & 240 & 231 & 226 & 230 & 229 \\
\hline $\begin{array}{l}\Delta t_{\mathrm{s}} \text { (the time needed for slope failure from } \mathrm{SO}_{4}{ }^{2-} \text { concentration analysis; } \\
\left.\Delta t_{\mathrm{s}}=t_{\mathrm{sf}}-t_{\mathrm{si}}, \mathrm{min}\right)\end{array}$ & 30 & 21 & 16 & 20 & 19 \\
\hline$S_{\mathrm{i}}\left(\right.$ the $\mathrm{SO}_{4}{ }^{2-}$ concentration value corresponding to $\left.t_{\mathrm{si}} ; \mathrm{mg} / \mathrm{l}\right)$ & 11.7 & 12.2 & 15.0 & 14.5 & 15.0 \\
\hline$S_{\mathrm{f}}\left(\right.$ the $\mathrm{SO}_{4}{ }^{2-}$ concentration value corresponding to $\left.t_{\mathrm{sf}} ; \mathrm{mg} / \mathrm{l}\right)$ & 21.7 & 22.4 & 25.1 & 23.6 & 25.5 \\
\hline $\begin{array}{l}\Delta S \text { (the increment of } \mathrm{SO}_{4}{ }^{2-} \text { concentration value in the time } \\
\left.\text { period of } \Delta t_{\mathrm{s}} ; \mathrm{mg} / \mathrm{l}\right)\end{array}$ & 10 & 10.2 & 10.1 & 9.1 & 10.5 \\
\hline $\begin{array}{l}\% \Delta S \text { (the increase rate of } \mathrm{SO}_{4}{ }^{2-} \text { concentration value in the } \\
\left.\text { time period of } \Delta t_{\mathrm{s}} ; \%\right)\end{array}$ & 85 & 84 & 67 & 63 & 70 \\
\hline
\end{tabular}

Table 5 Average values of the tests of Shenmu and Fengchiou

\begin{tabular}{|c|c|c|c|}
\hline \multirow[t]{2}{*}{ Test results } & \multicolumn{3}{|l|}{ Location } \\
\hline & Shenmu ( 2 sets) & Fengchiou (3 sets) & Average value of the 5 tests \\
\hline $\begin{array}{l}\text { Average } \Delta t_{\mathrm{d}} \text { (average time needed for primary failure from displacement } \\
\text { analysis; } \mathrm{min} \text { ) }\end{array}$ & 28.5 & 14.0 & 21.3 \\
\hline Average $\Delta t_{\mathrm{e}}$ (average time needed for slope failure from EC analysis; min) & 45.5 & 43.0 & 44.3 \\
\hline $\begin{array}{l}\text { Average } \Delta t_{\mathrm{s}} \text { (average time needed for slope failure from } \mathrm{SO}_{4}{ }^{2-} \\
\text { concentration analysis; min) }\end{array}$ & 25.5 & 18.3 & 21.9 \\
\hline $\begin{array}{l}\text { Average } \Delta E C \text { (average increment of EC value in the } \\
\text { time period of } \Delta t_{\mathrm{e}} ; \mu \mathrm{s} / \mathrm{cm} \text { ) }\end{array}$ & 39.0 & 39.3 & 39.2 \\
\hline Average $\% \Delta \mathrm{EC}$ (average increase rate of $\mathrm{EC}$ in the time period of $\Delta t_{\mathrm{e}} ; \%$ ) & 58.0 & 41.0 & 49.5 \\
\hline $\begin{array}{l}\text { Average } \Delta S \text { (average increment of } \mathrm{SO}_{4}{ }^{2-} \text { concentration value in the } \\
\left.\text { time period of } \Delta t_{\mathrm{s}} ; \mathrm{mg} / \mathrm{l}\right)\end{array}$ & 10.1 & 9.9 & 10.0 \\
\hline $\begin{array}{l}\text { Average } \% \Delta S \text { (average increase rate of } \mathrm{SO}_{4}{ }^{2-} \text { concentration value in the } \\
\text { time period of } \Delta t_{\mathrm{s}} ; \% \text { ) }\end{array}$ & 85.0 & 67.0 & 76.0 \\
\hline
\end{tabular}

From the seepage water quality observation view, before general slope failure, electrical conductivity (EC) and sulfate ion $\left(\mathrm{SO}_{4}{ }^{2-}\right)$ concentration of the seepage water showed an increasing tendency. The average increments and increase rates for $\mathrm{EC}$ and $\mathrm{SO}_{4}{ }^{2-}$ concentration, namely, $\Delta \mathrm{EC}, \% \Delta \mathrm{EC}, \Delta S$ and $\% \Delta S$, were $39.2 \mu \mathrm{s} / \mathrm{cm}$, $49.5 \%, 10.0 \mathrm{mg} / \mathrm{l}$ and $76.0 \%$, respectively.

From time period observation view, when displacement was used for monitoring slope failure, there were $21.3 \mathrm{~min}$ (average $\Delta t_{\mathrm{d}}$ ) for response before mass movement hazards. When the $\mathrm{EC}$ and $\mathrm{SO}_{4}{ }^{2-}$ concentration of the seepage water were used for monitoring slope failure, there were $44.3 \mathrm{~min}$ (average $\Delta t_{\mathrm{e}}$ ) and $21.9 \mathrm{~min}$ (average $\Delta t_{\mathrm{s}}$ ), respectively, for the response time. Therefore, it could be concluded compared with monitoring of displacement when EC of the seepage water was monitored, there were a longer time for response. This might because the EC of the seepage water was more sensitive to the local failure of the slope.

From observing the whole experimental process and from the slope displacement observation view, it could be found that general slope failure did not occur while the displacement of slope started to appear. It was more likely that small deformation occurred first in the soil mass of the slope and then through the rise of seepage water level and with the increase of displacement finally resulting in general slope failure. From local failure to general failure of the slope, displacement seepage water quality more or less reflected the information of the slope failure process.

When the traditional slope displacement monitoring method is used in the field, it is rather difficult to predict the location of local failure of the slope. In this study, variation of seepage water quality was used for monitoring mass movement, and from the results, it was found that the response time for mass movement by monitoring EC $\left(\Delta t_{\mathrm{e}}\right)$ was about twice as long as that by monitoring displacement $\left(\Delta t_{\mathrm{d}}\right)$. However, the conclusions as drawn in this study are limited in observing tests in the laboratory; and whether local failure of the slope is the reason why $\Delta t_{\mathrm{e}}$ is greater $\Delta t_{\mathrm{d}}$ is not completely understood and therefore, it needs further study. 
The observation method of seepage water quality was proposed to analyze and monitor mass movement. The proposed method is rather different from the traditional observation method for monitoring mass movement. However, the situations in the field are much more complicated than those in the laboratory. For instance, in the field, apart from being affected by mass movement, seepage water quality may be influenced by other factors such as point and non-point source pollution. In addition, the direction and the depth of seepage water are difficult to be detected. Before the proposed method is applied in the field, there are still a number of problems needing to be solved. For example, how to avoid the interference to groundwater quality by the external environment, how to orientate the observation holes and the depths to monitor the seepage water quality, whether there is threshold of the change in groundwater quality during the mass movement occurrence, if yes, how much will that be, how to implement the real-time monitoring, and whether the findings in this study are valid for slopes with different soils. Aside from these, the mechanisms of variation of groundwater quality and mass movement need to be further examined in the future.

For groundwater quality monitoring in the field, we selected three observation holes near the outlets of the watersheds of the streams at Shenmu and Fengchiou. Upstream of the holes, there were no residential, agricultural, or recreational activities. At the observation stations, automatic recording rain gages, groundwater level meters, electrical conductivity (EC) sensors, automatic samplers for collecting water samples, data loggers and wireless transmitters were installed for monitoring in the field. Although there were some data, there was no conclusive result.

\section{Conclusions and suggestions}

In this study, five sets of seepage tests were conducted in the laboratory. All processes of slope failure, displacements and seepage water quality were observed. From the displacement analysis, it was found that from the start of slope displacement till general slope failure, displacement versus time curve could be divided into two parts, namely, the initial failure displacement stage and primary failure displacement stage. All mass movements occurred in the primary failure displacement stage.

From observing displacement and seepage water quality, it was found that a certain time before general slope failure, displacement, EC and sulfate ion concentration value increased significantly. The time periods are helpful for response of hazard prevention. Among the three noted values, EC increased rapidly in the earliest time. This might be because EC was more sensitive to the local failure of the slope. In addition, compared with the monitoring method of displacement, the monitoring method of EC in the field is better, because local failure of the slope is difficult to be detected by displacement monitoring. Usually, when the sign of slope failure was detected using displacement monitoring, the displacement had already fallen into the primary failure displacement stage. However, it was possible to detect the occurrence of local slope failure using EC monitoring. Based on the findings in this study, compared with the displacement monitoring, the EC monitoring showed its superiority for monitoring mass movement.

In this study, the observation method of groundwater quality was proposed for monitoring mass movement. However, if the proposed method is to be used in the field, there are still problems that need to be solved. For instance, how to allocate the locations and the depths of the observation holes, how to prevent groundwater quality from interference by the external environment, whether there is threshold of change of groundwater quality while the mass movement occurs, if yes, how much will that be, and whether the findings in this study are valid for the slopes with different soils, and how to conduct the real-time monitoring, etc. Besides, the mechanisms of variation of groundwater quality and mass movement need to be further studied. Forecasting the occurrence of mass movement in the field by monitoring groundwater quality is yet to be further researched. However, it is anticipated that the findings in this study could be a small step toward this final goal.

Acknowledgments The authors are grateful to National Science Council and Soil and Water Conservation Bureau, Council of Agriculture in Taiwan, Republic of China, for their financial aid and assistance in generously providing necessary information.

\section{References}

Aoki S (1998) Geological features and underground water investigation of landslide ground. Proceedings of the conference on plan and mitigation technology of landslides. Taichung, Taiwan, September 17: 2-1 20

ASTM (2003) Standard test method for unconsolidated-undrained triaxial compression test on cohesive soil. ASTM designation: D2850-03a, 2 February 2003

ASTM (2004a) Standard test method for consolidated undrained triaxial compression test for cohesive soils. ASTM designation: D4767-04, 1 November 2004

ASTM (2004b) Standard test method for direct shear test of soils under consolidated drained conditions. ASTM designation: D3080-04, 1 November 2004

Bertram GE (1973) Field tests for compacted rockfill. In: Hirchfeld RC, Poulos SJ (eds) Embankment-dam engineering. Wiley, New York, pp 1-19

Chang TC, Chien YH (2007) The application of genetic algorithm in debris flows prediction. Environ Geol 53:339-347 
Chen RH, Lin ML, Chen H (1995) Mechanism of initiation of debris flow. In: Cheng FY, Sheu MS (eds) Urban disaster mitigation the role of engineering and technology. Elsevier, New York, pp 231-243

Das BM (1998) Principles of geotechnical engineering, 4th edn. PWS, Boston, pp 567-626

Fan JC, Liu CH, Wu MF (2003) Determination of critical rainfall thresholds for debris-flow occurrence in central Taiwan and their revision after the 1999 Chi-Chi great earthquake. Proceeding of 3rd international DFHM conference, Davos, Switzerland, pp 103-114

Houston SL, Walsh KD (1993) Compaction of rock correction methods for compaction of clayey soil. J Geotech Eng 119(4):763-778
Ibe KM, Ebe AM (2000) Impacts of debris-flow deposits on hydrogeochemical processes and the development of dryland salinity in the cross-river catchment, SE, Nigeria. Environ Monit Assess 64:449-456

Lambe TW, Whitman RV (1979) Soil mechanics, SI version. Wiley, New York, pp 352-373

Lin PS (1986) A study on engineering properties of compacted lateritic gravels. J Chin Inst Eng 9(6):533-545

Parsons RL, Foster DH, Cross SA (2001) Compaction and settlement of existing embankment. Report No. K-TRAN: KU-00-8. The University of Kansas, Lawrence 